\title{
Identification and Characterization of Maitara Island Clay, North Maluku
}

\author{
Deasy Liestianty ${ }^{1}$, Muliadi ${ }^{*}$, Marhan ${ }^{1}$, Said Hi Abbas ${ }^{2}$, Yanny ${ }^{3}$ \\ ${ }^{1}$ Department of Chemistry Education, Faculty of Teacher, Learning and Education, Universitas Khairun \\ ${ }^{2}$ Department of Mechanical Engineering, Faculty of Engineering, Universitas Khairun \\ ${ }^{3}$ Department of Mining Engineering, Faculty of Engineering, Universitas Muhammadiyah Maluku Utara
}

\begin{abstract}
Characterization and identification of Maitara Island clay have been carried out. This study aims to determine the types of minerals contained in the Maitara Island clay. The analytical methods used include X-Ray Fluorescence (XRF) to determine the chemical composition of Maitara Island clay, X-Ray Diffraction (XRD) for mineralogical analysis of Maitara Island clay, Fourier Transmission Infra Red (FTIR) to determine the types of vibrations that exist between the atoms in clay minerals from Maitara Island, and Scanning Electron Microscopy (SEM) to determine the morphology of clay minerals. XRF analysis showed that silica was the element found to dominate the clay minerals with a percentage of $40.79 \%$. Moreover, the highest oxide component found was $\mathrm{SiO}_{2}$ with a percentage of $87.25 \%$. XRD analysis indicated that the Maitara Island clay minerals are composed of montmorillonite, magmatite, aluminum oxide colondrum, cristobalite, lime, titanium oxide, and hematite. The results of FTIR analysis denoted the presence of silica as silanol and siloxane. SEM images showed angular grains which signified silica as the main component in the clay minerals of Maitara Island
\end{abstract}

Keywords: X-Ray Fluorescence, X-Ray Diffraction, Scanning Electron Microscopy

\section{Introduction}

Indonesia has abundant natural mineral resources ranging enclosed within its grounds such as clay. One of its areas that contains abundant mineral content is North Maluku province. The North Maluku Province possesses tremendous potential in producing minerals such as gold, copper, manganese, iron, iron sand, coal, nickel ore, natural gas, limestone and marble $[1,2,3,4]$. Within the province the largest geological resource content was found on Bacan Island at around 70 million tons. It holds minerals such as manganese, chromite, limestone, calcite, bentonite, diatomaceous, talc, kaolin, pearlite, magnesite, andesite, sandstone, pumice, diorite, and other various precious rocks [5]. In addition to Bacan Island, an area ought to be explored for its clay minerals is the Maitara Island.

Clay minerals are minerals that possess special properties, including the abilities to swell and shrink. Such phenomena of behaviors are directly related to changes in water content in a material containing clay minerals [6]. Clay minerals that are able to experience swelling include the smectite group (montmorillonite, saponite, beidellite, etc.). For its ability to swell, this group presence in an area should be paid close attention to, especially in the occasions of underground mine opening. Clay is a mineral particle containing finely fused silica and/or aluminum. Silicon, oxygen, and aluminum are the elements that make up most of the Earth's crust. Clay is formed from the weathering of silica rock $\left(\mathrm{SiO}_{2}\right)$ by carbonic acid $\left(\mathrm{H}_{2} \mathrm{CO}_{3}\right)$ and partly from geothermal activity. Clay is classified based on the arrangement of layers of silicon oxide and aluminum oxide that form its crystals [7]. Clay can be used as a catalyst adjuvant, adsorbent or resin for cation exchange [8].

Studies on the types of clays found in Indonesia have been widely reported. Ansori [9] revealed that clays in Sruweng and Pejagoan, Kebumen, contain kaolinite, montmorillonite, illite and parent minerals. Identification and characterization of clay minerals from the Bomban Valley reported by Gonggo [10] showed that the main constituent of the clay found with a percentage of $56.26 \%$ was silica in the form of cristobalite and quartz as well as aluminum oxide in the form of kaolin, anorthite, and illite. Maitara Island is one of the islands of the North Maluku province located between the Tidore Island and the south of Ternate Island. The island is a naturally formed small island chunk. The identification of clay mineral content of the Maitara Island has never been reported. The purpose of this research is to identify and characterize the types of clay minerals found on Maitara Island. Mineral identification and characterization were carried out

\footnotetext{
* Corresponding author : $\underline{\text { muliadiunkhair@gmail.com }}$
} 
using $\mathrm{x}$-ray fluorescence (XRF), x-ray diffraction (XRD), Fourier transform infrared (FT-IR) and scanning electronic microscopic instrumentations $[9,10,11]$

\section{Methodology}

Clay mineral was sampled on Maitara Island with at the $0^{\circ} 43^{\prime} 56.000$ North Latitude and $127^{\circ} 22^{\prime} 16.000$ East Longitude coordinates. Samples were grinded to a uniform size of 80 mesh. The fine powdered clay samples were then characterized using $\mathrm{x}$-ray fluorescence (XRF), x-ray diffraction (XRD), fourier transform infrared (FT-IR) and scanning electronic microscopic (SEM) instrumentations. XRF and XRD analyses were carried out by placing clay powder sample on a sample holder, whereby the sample would then be exposed to $\mathrm{x}$-rays beam on its surface. In another analysis, clay sample was coated with $\mathrm{Pt}$ to be observed using SEM at a magnification range of 1500 to 8000 times to perceive image of the size and shape of the clay particles. FTIR analysis was done using $\mathrm{KBr}$ which was ground with the samples and pressed into pellets. The samples were then subjected to infrared light for analysis.

\section{Results and Discussion}

XRF characterization results of Maitara island clay samples are shown in Table 1. Based on the results of XRF analysis, some of the constituent elements of Maitara clay minerals are known to be silica (40.79\%), potassium $(4.33 \%)$, iron $(2.81 \%)$, calcium $(1.91 \%)$, and titanium $(0.91 \%)$. The results also indicated that $\mathrm{SiO}_{2}$ minerals were the main oxide minerals contained in Maitara Island clay with a percentage of $87.25 \%$, while other oxide minerals were $\mathrm{K}_{2} \mathrm{O}(5.21 \%), \mathrm{Fe}_{2} \mathrm{O}_{3}(4.01 \%)$, $\mathrm{CaO}(2.66 \%)$, and $\mathrm{TiO}_{2}(0.366 \%) . \mathrm{SiO}_{2}$ minerals as the minerals with the highest content in Maitara clay is in accordance with research conducted by [10] which revealed that the oxide mineral with the highest content in the clay minerals of Boban valley village was $\mathrm{SiO}_{2}$ $(56.26 \%)$.

Table 1. XRF analysis of results Maitara Island clay

\begin{tabular}{|c|c|c|c|}
\hline $\begin{array}{c}\text { Oxide } \\
\text { Compounds }\end{array}$ & $\mathrm{m} / \mathrm{m} \%$ & Elements & $\mathbf{m} / \mathbf{m} \%$ \\
\hline $\mathrm{K}_{2} \mathrm{O}$ & 5,21 & $\mathrm{~K}$ & 4,33 \\
\hline $\mathrm{Fe}_{2} \mathrm{O}_{3}$ & 4,01 & $\mathrm{Fe}$ & 2,81 \\
\hline $\mathrm{CaO}$ & 2,66 & $\mathrm{Ca}$ & 1,90 \\
\hline $\mathrm{TiO}_{2}$ & 0,366 & $\mathrm{Ti}$ & 0,219 \\
\hline $\mathrm{MnO}$ & 0,234 & $\mathrm{Mn}$ & 0,181 \\
\hline $\mathrm{SrO}$ & 0,0755 & $\mathrm{Sr}$ & 0,0638 \\
\hline $\mathrm{ZrO}_{2}$ & 0,063 & $\mathrm{Zr}$ & 0,0469 \\
\hline $\mathrm{BaO}$ & 0,035 & $\mathrm{Ba}$ & 0,032 \\
\hline $\mathrm{Rb}_{2} \mathrm{O}$ & 0,0231 & $\mathrm{Rb}$ & 0,0211 \\
\hline $\mathrm{Nb}_{2} \mathrm{O}_{5}$ & 0,0195 & $\mathrm{Nb}$ & 0,0136 \\
\hline $\mathrm{MoO}_{3}$ & 0,0134 & Mo & 0,0089 \\
\hline $\mathrm{SnO}_{2}$ & 0,0063 & $\mathrm{Sn}$ & 0,0050 \\
\hline $\mathrm{In}_{2} \mathrm{O}_{3}$ & 0,0062 & In & 0,0051 \\
\hline $\mathrm{RuO}_{4}$ & 0,0056 & $\mathrm{Ru}$ & 0,0043 \\
\hline
\end{tabular}

Characterization of clay samples using XRD was carried out to determine the types of minerals contained based on peaks found at $2 \theta$ angles of $5^{\circ}$ to $60^{\circ}$. The XRD diffractograms of the Maitara island clay samples are presented in Figure 1.

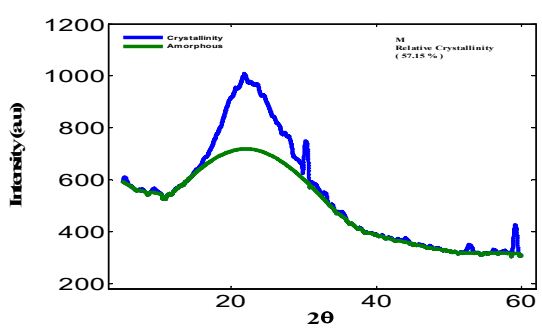

Fig.1. Results of XRD analysis results of Maitara Island clay minerals

Based on the XRD diffractograms shown in Figure 1 , the minerals contained within the clay consist of cristobalite, indicated by $2 \theta=22^{\circ}$, quartz, indicated by $2 \theta=27^{\circ}$, maghmetite, denoted by $2 \theta=15^{\circ}$ and $60^{\circ}$, aluminum oxide colondrum, indicated by $2 \theta=45^{\circ}$, lime, signified by $2 \theta=38^{\circ}$, and titanium, indicated by $2 \theta=$ $25^{\circ}$. The minerals present in the Maitara Island clay corresponds to the research conducted by [10]. The research revealed $\mathrm{SiO}_{2}$ oxide found in the boban village clay had the mineral structures of quartz and cristobalite. Additionally, there were also oxides of $\mathrm{Al}_{2} \mathrm{O}_{3}, \mathrm{CaO}$, $\mathrm{TiO}_{2}$, and $\mathrm{Fe}_{2} \mathrm{O}_{3}$. The $2 \theta$ values found were also in accordance with JCPDS data of quartz, JCPDS No. 461045, Cristobalite JCPDS No. 39-1346, Maghemite JCPDS No. 39-1346, $\mathrm{Al}_{2} \mathrm{O}_{3}$ JCPDS No. 11-0517, $\mathrm{CaO}$ JCPDS No. 002-1088, and $\mathrm{TiO}_{2}$ JCPDS No. 21-1272. The $2 \theta$ angles which indicated the presence of silica compounds $\left(\mathrm{SiO}_{2}\right)$ were $2 \theta=22^{\circ}$ and $27^{\circ}$, each signifying cristobalite and quartz minerals respectively. Moreover, the cristobalite was found to be the most abundant silica mineral with the highest peak showing at a value of $2 \theta=22^{\circ}$. This finding is in accordance with $[11,12]$ which stated that all silica minerals show a peak at a value of $2 \theta=22^{\circ}$. The specific angle was determined to indicate cristobalite as the mineral with the highest composition in clay, corresponding to [13] which revealed that the characteristic $2 \theta$ value of cristobalite is $22^{\circ}$.

Tests using FTIR were carried out to determine the types of silica oxides contained in the clay. In this analysis the wavelength range observed was $4000-500 \mathrm{~cm}^{-1}$. The results of the FT-IR analysis are shown in Figure 2.

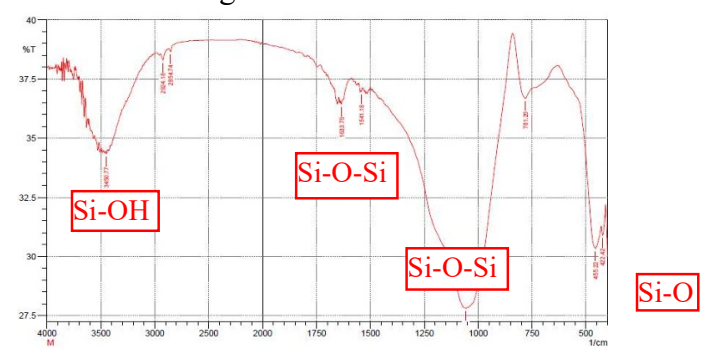

Fig.2. FTIR spectra of Maitara Island clay minerals 
In Figure 2, silica can be observed at the wave number of $3450.77 \mathrm{~cm}^{-1}$, signifying the silanol group ( $\equiv \mathrm{Si}-\mathrm{OH}$ ), and the wave number of $1633.76 \mathrm{~cm}^{-1}$ from the siloxane group $(\equiv \mathrm{Si}-\mathrm{O}-\mathrm{Si})$. These absorption peaks are in line with the study of [14] which revealed the silanol group at the wave numbers $3400-3500 \mathrm{~cm}^{-1}$ and the siloxane group at the wave numbers $1600-1700 \mathrm{~cm}^{-}$ ${ }^{1}$. In addition, the presence of silica was also observed at a wavelength of $1000 \mathrm{~cm}^{-1}$, which denoted the siloxane group and at a wavelength of $455.22 \mathrm{~cm}^{-1}$ which indicated the Si-O bending vibration. Similarly, the vibrations observed are in accordance with the findings of [15] which claimed that within the range of $1000 \mathrm{~cm}$ ${ }^{-1}$ and $400 \mathrm{~cm}^{-1}$, the vibrations of the siloxane functional groups, i.e., $\mathrm{Si}-\mathrm{O}-\mathrm{Si}$ and $\mathrm{Si}-\mathrm{O}$ vibrations, are present. The result thus signified the presence of silica content in Maitara Island clay.

SEM testing was carried out to determine the morphology of the Maitara island clay in which it was carried out at 1500 and $8000 x$ magnifications. The SEM images of Maitara Island clay minerals obtained are shown in Figure 3.

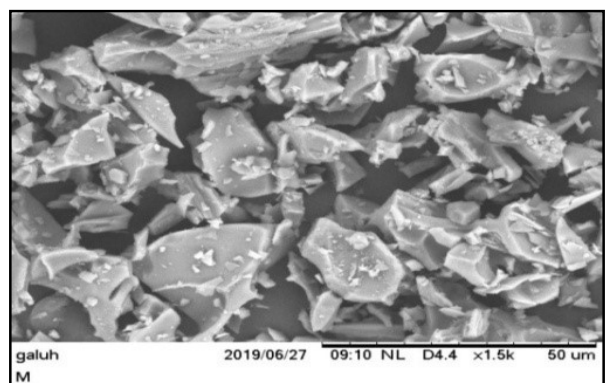

(a) $1500 \mathrm{x}$ magnification

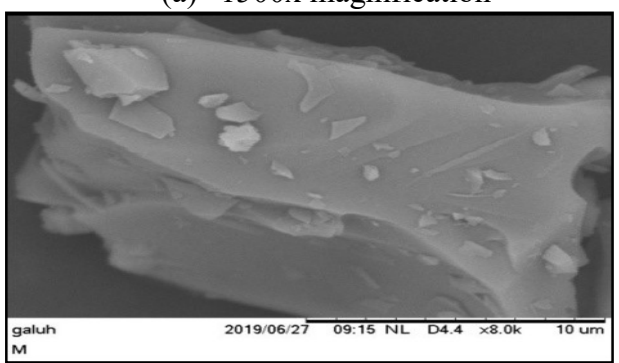

(b) 8000x magnification

Fig. 3. Scanning Electron Microscopic images with (a) 1500x magnification and (b) $8000 x$ magnification.

Figure 3 displays sharp-angled grains which indicate a high percentage of silica minerals relative to the existence of impurities. The sharp-angled grains produced are of the angular silica grain structure type. This is in accordance with previous researches stating that the domination of angular grains in silica containing minerals indicates the presence of silica in the material with relatively small impurity $[16,17]$. The appearance of a large surface area indicated good crystallinity, as mentioned by [7] which claimed that the SEM and XRD analysis results of clays that displace larger surface indicate good crystallinity.

\section{Conclusion}

Maitara island clay contains silica oxide minerals with a percentage of $87.27 \%$ in the form of siloxane and silanol. Thus, the main compound found in Maitara clay is silica. The types of minerals identified in the Maitara island clay are montmorillonite, quartz, cristobalite, maghmetite, aluminum oxide colondrum, lime, and titanium oxide minerals.

We are thankful to the LPPM Universitas Khairun for the funding of the research in scheme of Penelitian Unggulan perguruan Tinggi, 2021.

\section{References:}

1. N.W. Bambang, Sukmana, S. Syahya, Laporan Eksplorasi Endapan Mangan di Pulau Doi, Kecamatan Loloda Kepulauan, Kabupaten Halmahera Utara, Provinsi Maluku Utara, Pusat Sumber Daya Geologi, Bandung (2006).

2. S. Syahya, Inventarisasi Mineral Logam Di Kabupaten Halmahera Selatan Dan Kota Tidore Maluku Utara, Proceeding pemaparan hasil kegiatan lapangan dan non lapangan pusat sumber daya geologi (2007).

3. Suhandi, W. Suherman, Inventarisasi Potensi Bahan Galian Pada Wilayah Peti Daerah Halmahra Utara, Provinsi Maluku Utara, proceeding pemaparan hasil-hasil kegiatan lapangan dan non lapangan pusat sumberdaya geologi, Bandung (2006).

4. Yanny, M.M. Ibrahim, A. Jaya, A. Maulana, Muliadi, ARPN Journal of Engineering and Applied Sciences, 16, 10 (2021).

5. Laporan Kajian Ekonomi dan Keuangan Regional Provinsi Maluku Utara. Kantor Perwakilan Bank Indonesia Provinsi Maluku Utara (2014).

6. L.D. Wesley, Mekanika Tanah untuk Tanah Endapan dan Residu, ANDI, Yogyakarta (2010)

7. M. Muslim, Karakterisasi Sifat Fisika Kimia Lempung dari Daerah Kecamatan Watu Lemo dan Durenan Kabupaten Trenggalek. Skripsi. Jurusan Kimia, Fakultas Sains dan Teknologi, Universitas Negeri Maulana Malik Ibrahim Malang (2014).

8. C.M. Bijang, S.J. Sekewael, J. A. Koritelu, Indo. J. Chem. Res, 1, 2(2014).

9. Ansori, Chusni. Jurnal Teknologi Mineral dan Batu Bara, LIPI, 6, 3 (20.10)

10. S.T. Gonggo, Jurnal Akademika Kimia, 2, 2 (2013).

11. Yanny, M.M. Ibrahim, A. Jaya, A. Maulana, Muliadi, J. Phys.: Conf. Ser. 1569 (2020).

12. N.R. Herdianita, H.L. Ong, E.A. Subroto, B. Priadi, Pengukuran Kristalinitas Silika Berdasarkan Metode Difraktometer Sinar-X. In Prociding ITB, 31,1. Institut Teknoloi Bandung (1999).

13. R.C. Breneman, and J.W. Halloran, Journal of the American Ceramic Society, 97, 7, (2014).

14. J. Latupeirissa and E.G. Fransina, Indonesian Journal of Chemical Research, 1, 2, (2014).

15. A. K. Ratri, S. Sriatun, and A. Darmawan, Jurnal Kimia Sains dan Aplikasi, 11, (2008). 
16. Azhari dan A. Muchtar, Jurnal Teknologi Mineral dan Batubara, 12, 3, (2016).

17. N. Fuadi, A.A, Amir, Jambura Physcis Journal, 2, 2, (2020) 